\title{
Strategy and business models - strange bedfellows? A case for convergence and its evolution into strategic architecture
}

\author{
G.M. Mansfield* \& L.C.H. Fourie \\ Graduate School of Business, University of Stellenbosch, \\ PO Box 610, Bellville 7535, Republic of South Africa \\ glenm@sun.ac.za
}

Received October 2003

\begin{abstract}
Strategy aims for sustainable competitive advantage; business models are said to be the sine qua non of value creation. Firms in the networked economy may ask which approach is the more relevant and whether either, or both, are sufficient for success - and then misinterpret the linkage between them. Internet-based businesses are faced with rapid change in an environment characterised by connectedness and choice in which dynamism, innovation and customer-centricity appear to be the winning ingredients for success. In the networked economy the internet with its open standards has created commercial arrangements which manifest a disdain for traditional boundaries and demand new patterns of management behaviour for effective performance. The classic approach to strategy formulation with its perceived indifference, for example, towards network formation, confusion around generic strategy deployment, lack of dynamism and its vacuous treatment of customer-centricity have led electronic business practitioners to the flawed conclusion that a business model is the only compelling strategic behaviour which predicates success. This conceptual paper builds a theoretical base which traces the roots of strategy and business models, reviews the context of each, postulates a relationship between these two fundamental approaches and offers some guidelines on the missing ingredients.
\end{abstract}

*To whom all correspondence should be addressed.

\section{Introduction}

The dot.com debacle suggests the existence of two illfounded beliefs among internet-spawned firms. The first is a disregard for the value of the process and content of traditional business strategy. The second misleading assumption, and possibly a key contributor to failed networked economy ventures, is the belief that a good business model alone, in an environment characterised by change and uncertainty, is sufficient for survival (Bertsch, Busbin \& Wright, 2002; Kanter, 2001; Krantz, 2000). This paper explores and contrasts the propositions in the context of the networked economy and finds them both wanting. It cannot be definitively stated that the current e-business environment represents a totally different, discontinuous change from the old; neither is there any guarantee that present and past environments share common features or imperatives for competitive advantage (Honda \& Martin, 2002; Kim, Nam \& Stimpert, 2001:5).

Understanding the role and relevance of strategy is necessary for the effective competitive behaviour of firms in the networked economy. It is postulated, for commercial firms to perform effectively in this environment, that a strategy based purely on conventional strategic approaches may also prove inadequate since 'during times of uncertainty, traditional approaches to formulating and implementing strategy are not sufficient. Traditional strategy approaches are grounded on assumptions of continuity and gradual evolution...' (Welborn \& Kasten, 2003:22). Strategy, however, has a positive contribution to make that is not irrelevant to firms in the economy of today.

\section{Background}

Strategy is that management behaviour concerned with the firm's creation of sustainable competitive advantage. Strategy reflects the sum of managerial choices and is a blend of deliberate actions, tactical responses and organisational learning. Effective strategy implementation requires that management build a strategy-focused organisation, allocate resources, establish policies, motivate and reward people, install systems and apply leadership (Thompson \& Strickland, 2001:3 \&19). It is the essence of how any endeavour, whether profit seeking or otherwise, establishes, sustains, grows and eventually, having made its economic contribution to stakeholders, exits its domain of activity. Regardless of whether the prevailing economic paradigm is agrarian, industrial, information or knowledgebased, corporate strategy remains that pattern of decisions defining the firm's products and markets, objectives, plans and range of business. It frames the economic, human and technological organisation and drives the creation of a return to all constituents. Strategy content includes the firm's market position, its resource deployment, and how it conducts its operations, attracts and satisfies customers, competes successfully and achieves organisational objectives. It is the way a firm attains its desired future.

Strategy formulation is one of the many tasks performed by management and is by no means an isolated function. As businesses evolved from operating in primitive markets, through barter behaviour to the instantaneous electronic exchanges of today, astute managers have endeavoured to incorporate broader perspectives in their thinking without 
losing focus. Latterly, as the networked economy blurred corporate boundaries through the creation of strategic alliances and online collaboration, so strategy, in order to remain relevant, has had to broaden its base to cater for the intra- and extra-organisational linkages between strategic entities.

\section{The contribution of strategy}

After studying several corporations in the United States, strategy writers in the 1940 s concluded that the most successful companies were centralised and excelled at goalsetting (Drucker, 1946; Sloan, 1963). Levitt (1960) viewed strategy from a broader perspective in which he maintained that a focused vision produced the best result. The formalised and academic measurement of strategy and strategic thinking, however, is rooted in the work of Chandler (1962). As one of the first writers on corporate diversification his definition of strategy included the setting of long-term goals and objectives, the determination of courses of action and the allocation of resources to achieve those objectives (Chandler, 1969). In the mid-1960s a blueprint for planning a firm's objectives, expansion plan, product-market positions and resource allocation was advocated by Ansoff (1968). The first attempt to quantify the specific relationship between strategy and performance came from the Boston Consulting Group, founded in 1964 (Henderson, 1989). A blend of market analysis and research with financial theory resulted in the quantification of performance and the development of an extensive database. In the mid-1970s the perspective of strategy research shifted towards strategic management and theories on organisational behaviour, economics, finance and marketing (Schendel \& Hofer, 1979) which eventually gave rise to strategy content research. The major thrust of the strategy content research explored linkages between environmental conditions, corporate or business-unit strategic decisions and economic performance (Koch, 2000).

Strategic management researchers have focused increasing attention on the concepts of strategic taxonomies frequently referred to as gestalts, strategic archetypes (Robinson \& Pearce, 1988) or generic strategies. These efforts aim to provide an empirical mechanism through which different strategies or patterns of strategic behaviour can be classified across a variety of industries. The taxonomy-oriented research stream has long been promulgated by strategy scholars as a means to the identification of interrelated strategy components, recognising that competitive strategies represent a network of interactions among the various constituent elements that ultimately make up a business strategy (Galbraith \& Schendel, 1983; Kim, et al., 2001).

Studies have been conducted on the effect of industry evolution and strategy (Anderson \& Zeithaml, 1984; Hambrick \& Schecter, 1983). This stream of research has a clear intent to establish the relationship between conditions leading to strategy and the resultant performance. The different stages of industry evolution are emergence, growth, shakeout, maturity and decline. Findings indicate that firms do pursue different strategies across different industry contexts and that particular strategic behaviours are most appropriate at specific stages; that is, they are associated with market share gains and profitability enhancement (Fahey \& Christensen, 1986:176). The findings also suggest that firms adapt their strategies as an industry evolves through its life cycle. Since the web is in a turbulent phase of early evolution relevant strategies will be characterised by frequent adaptation and change.

\section{Industry positioning}

In the formulation of strategy there is a need to locate the firm as a participant in an industry of similar organisations. The first influential work on strategy measurement comes from Porter (1980) who postulated that competitive advantage flowed from the industry position of the firm. He notes, 'The essence of formulating competitive strategy is relating a company to its environment,' and that, 'the key aspect of a firm's environment is the industry or industries in which it competes' (1980:3). He finds that the underlying determinants of the appropriate classification for an industry revolve around five competitive forces which drive industry competition: the threat of new entrants, bargaining power of buyers and suppliers, threat of substitute products or services, and inter-industry rivalry among existing firms. Based on an analysis of these five forces an industry may be classified as representing one of five generic industry environments: fragmented, emerging, mature, declining, or global. Latterly, with the insights of the drivers in the networked economy, Downes and Hui (1998) proposed adding three more forces, namely, those of globalisation, digitisation and deregulation. Unfortunately these addenda still predicate a relatively stable environment.

In what has become known as the positioning-based view (PBV) Porter further postulates that firms could earn monopoly rents either by selecting industries that are structurally attractive or by manipulating the forces driving competition. He proposes three potentially successful generic strategic approaches for creating a defensible position and outperforming competitors in a given industry: overall cost leadership; differentiation or the creating of a product or a service recognised industry-wide as being unique; and, focus in which the firm concentrates on a particular customer niche, geographic market or product line segment.

The relevance of Porter's framework to internet-based firms whose domain is characterised by turbulence and uncertainty remains the subject of academic debate. His generic strategy of cost leadership, for example, can be as viable a strategic choice for web-enabled commerce as it is for off-line businesses (Kim, et al., 2001). Low price suppliers remain appealing to price-sensitive online buyers. The web facilitates price comparisons by making tools available which reduce search costs and thus enables customers to benefit from nearly perfect information, acquired at little or no cost (Bakos, 1997). However, pursuit of the lowest price is not necessarily the reason customers purchase items on the web as indicated in a study by $\mathrm{J} P$ Morgan (1999). This survey highlighted support as the main criterion for such customers. Price was important only to $19 \%$ of the respondents. 
A successful differentiation strategy is built on factors including design, brand image, reputation, technology, product features, networks and differentiated customer service (Kim, et al., 2001). Differentiation should not be imitable. Such differentiating elements are applicable to internet firms.

Porter's focus strategy targets specific groups of buyers or product lines. These strategies rely on low costs or differentiated products and services. A new entrant web firm can compete against large established firms by focusing on a particular niche, such as eBay taking on Sotheby in the auction market (Cohen, 2002). A focused strategy increases the chance of survival and success and may function as an entry barrier. Lower investment levels required by online businesses enable lower break-even points. Thus, targeting even small market segments can be a viable strategy for online firms. Customers may be easily connected with firms that focus on niche markets due to the web's pervasive search capabilities (Kim, et al., 2001:6).

\section{The resource-based view of the firm}

Needing to go beyond the industry explanation gave rise to the resource-based view (RBV) of the firm. The basic principles have been extensively documented and reviewed (Barney, 1991; Hamel \& Prahalad, 1990; Priem \& Butler, 2001). This view of the firm builds on Schumpeter's (1934) perspective of value creation which views the firm as a collection of resources and capabilities. This perspective, more than that of strategy, begins to parallel the concept of the business model.

The RBV posits that marshalling and uniquely combining a set of complementary, specialised resources and capabilities can create value (Rayport \& Jaworski, 2001: 79-87). These capabilities are heterogeneous within an industry, are scarce, durable, not easily traded and difficult to imitate (Barney, 1991; Hamel \& Prahalad, 1990 \& 1994). Such resources and capabilities are valuable if they reduce a firm's costs or increase its revenues compared to what would have been the case if the firm did not possess those resources. Utilisation of the resource is more important than its possession and a resource only becomes a competitive advantage when it is applied to an industry and brought to market (Kay, 1993).

It can be seen from the above that the Porter and RBV frameworks are not mutually exclusive. Also evident is how strategy mediates between the organisation and its environment. The internet, however, has introduced changes in resource markets. The economic environment is moving towards networks, open markets, mobile labour and information abundance.

Resources are becoming increasingly tradable and the advantages accruing from market position and strategic imitation are falling (Fahy \& Hooley, 2002). Careful analysis of an enterprise's web-related activities and that of its stakeholders now give clues to its competencies (such as alliances, vendors, value chain, technologies, skills and pricing policies) previously invisible to a competitor. Such transparency facilitates the imitability of competencies. In fluid resource markets sustainable advantage is reinforced by assets that are not easily discernable.

The resource-based approach to strategy has gradually become a perspective that combines realism with rigour but has shortcomings. 'The debate over the resource-based view has so far been largely conducted either theoretically or empirically at the macro-level, with large-scale statistical studies the weapon of choice. ...With no firm conclusions emerging, the macro approach to the resource-based view is in danger of failing to deliver against its promises' (Johnson, Melin \& Whittington, 2003:6). To add complexity to the $\mathrm{RBV}$ in the networked economy is the increasing criticism against it for failing to show where and when knowledge resources are of competitive advantage (Zack, 1999).

Internet-based businesses are dynamic and have learnt to cope with and adapt to rapid changes in what has become a hyper-competitive environment (D’Aveni, 1994 \& 1998) in which speed, surprise and innovation are the winning bases of competitive advantage (Brown \& Eisenhardt, 1997). Hyper-competition impacts both the level and the frequency of strategy activity. Fast and innovative responses to competition require organisational decentralisation moving strategic decisions to line managers who are closer to the customers. Strategic innovation increasingly involves managers at the periphery, rather than just those at the centre (Hamel \& Prahalad, 1996). The hypercompetitive situation takes strategy-making from measured cycles into a much more continuous process (Brown \& Eisenhardt, 1997). Strategy formulation has become a routine feature of organisational life. With its impact on level and frequency, hyper-competition makes of strategy something in which more people are involved, more often than ever before. Progress on content issues in strategy is beginning to rely increasingly on a 'micro perspective view' (Johnson, et al., 2003:6).

In the traditional pre-internet economic paradigm, the position- and resourced-based views have tended to dominate the academic strategy debate as they endeavour to explain the variance in the performance of businesses. These perspectives were developed and published in times of a more predictable economic environment than the one prevailing today. Developments surrounding the internet have brought about significant change. Just how material these changes are, and what new demands are made on strategy, need to be explored in an economic context.

\section{The economic landscape}

The new drivers of growth have introduced fundamental economic change. Such developments could begin to question the role of traditional competitive behaviour and the appropriateness and validity of its associated strategies in this environment. In the e-business literature various writers (Kalakota \& Robinson, 2001; Rayport \& Jaworski, 2001; Tapscott, Ticoll \& Lowy, 2000) echo the sentiments of strategic management authors, Thompson and Strickland (2001:225), who maintain that 'the impact of the internet and the rapidly emerging e-commerce environment is profound. ... There can be no doubt that the internet is a driving force of revolutionary proportions'. Developments 
of this magnitude that impact on the entire world do not happen very often. When they do, it may seem as if the old rules no longer apply. Although this is a widely accepted popular proposition it is a view not necessarily shared by all.

The new drivers of technology and inter-connectivity have changed ways in which economic entities interact. The choices now available to customers, management's knowledge of competitor behaviour such as dynamic pricing and channels used for delivering knowledge content, have introduced new behaviour. When the telephone enabled communications and mechanisation produced the production line, firms had the choice, at their peril, of ignoring the shock created by these interventions or embracing the concomitant benefits. This same dilemma faces business today.

In the networked economy, economics is no longer the study of scarcity. Customers are confronted with abundance, as many of the non-physical, knowledge-based products of the networked economy are reproduced and distributed at nearzero marginal cost (Tapscott, et al., 2000:5) making the creation of value that much more of a central purpose in today's businesses. The new drivers in the economy and the changes in the environment have encouraged some entrepreneurs to adopt novel approaches to value creation. In doing so, however, some businesses have irrationally overstepped the mark and almost abandoned strategy along with its rich and valuable heritage, the point made earlier.

\section{The concept of value and the rise of the business model}

Competitive behaviour is the rationale for business strategy development - a truism in any free market. Customer interconnectivity has driven firms to disregard traditional boundaries and raised inter-firm collaboration to heights not seen before. Value creation can now be shared among firms from different industries and in vastly different geographical locations (Awad, 2002). The reach of the internet enables customers to have a wider choice and be better informed than ever before (Evans \& Wurster, 1999). Such challenges exist in the dynamic, networked and highly competitive domain of the e-commerce firm.

Traditional approaches to strategy formulation and the perceived indifference of strategy content towards alliance formation (Tapscott, 2001), confusion around generic strategy deployment (Murray, 1988), its lack of dynamism (Eisenhardt \& Martin, 2000) or focus on customer-centricity (Hax \& Wilde, 2001), all of which are becoming prerequisites for success in the networked economy, have driven some internet-spawned businesses to seek new ways of competing and creating value in virtual markets.

Value opportunities from non-traditional sources are embedded in digital exchanges. Value is a prized commodity that has exchange potential in an open market. The characteristics of virtual markets impacting on valuecreating economic transactions include the ease of extending a product range to include complementary products, improved access to complementary assets, new alliances among firms, the potential reduction of asymmetric information among economic agents through the internet medium, and real-time customisability of products and services (Amit \& Zott, 2001). Industry boundaries become porous as value chains are redefined (Sampler, 1998). This in turn may affect the scope of the firm as opportunities for outsourcing arise in the presence of reduced transaction costs and increased returns. A transaction occurs when a good or service is transferred across a technologically separable interface; when one stage of processing terminates and another begins (Williamson, 1983). Value creation flows from cost reductions through transaction efficiencies. One of the main benefits of transacting over the internet, or in any highly networked environment, is the reduction in transaction costs it engenders.

According to a recent survey the cost of sending 1 trillion bits electronically has, over the past 30 years, dropped from $\$ 150,000$ to $\$ 0.12$ (Economist, The, 2000:6). This development, coupled with the emergence of virtual markets, has changed the way companies operate and structure economic exchanges.

The opportunity for wealth creation which has become available is not a recent phenomenon. Early examples of value creation through structural innovation became evident in the early 1900s as vertically-integrated, industrial corporations began to feature strong supply-chain hierarchies. This led to businesses making process and structural innovations which resulted in new ways of production, for example, through collaborative networks leading to outsourcing and the formation of virtual corporations (Tapscott, et al., 2000:14-15).

Economic development and new value creation through the process of technological change and innovation first observed by Schumpeter, identified several sources of innovation, or value creation, including the introduction of new goods or new production methods, the creation of new markets, the discovery of new supply sources and the reorganisation of industries. Schumpeter's notion of creative destruction (Becker \& Knudsen, 2002:394) was developed after noting that certain economic rents, or income streams, become available to entrepreneurs following disruptive technological change. These diminished once the innovation became an established practice. Schumpeter (1934) highlighted the contribution of individual entrepreneurs and placed an emphasis on the innovations and services rendered by the new combinations of resources. Firms may differ in terms of the resources and capabilities they control until some exogenous change, or Schumpeterian shock, occurs. Value creation in virtual markets comes from exploiting relational capabilities and complementarities between a firm's resources and its capabilities, for example, between online and offline capabilities.

In the mid-1980s, Porter published a framework analysing the process of value creation at the organisational level. He defines value as 'the amount buyers are willing to pay for what a firm provides them. Value is measured by total revenue. A firm is profitable if the value it commands exceeds the costs involved in creating the product' (Porter, 
1985:38). Porter's analysis identifies activities of the firm with their concomitant economic implications. It includes defining the strategic business unit, identifying critical activities, defining products, and determining the value of an activity. The value chain framework addresses the activities a firm should perform. It identifies the configuration of the firm's activities that enable it to add value to its products and compete in its industry. Value chain analysis concentrates on the primary activities having a direct impact on value creation, and support activities affecting value only through their impact on the performance of the primary activities. He posits that value can be created by differentiation through activities that reduce buyer costs or raise buyer performance. The drivers of product differentiation, and hence sources of value creation, are policy choices, linkages within the value chain or with suppliers and channels, timing (of activities), location, sharing of activities among business units, learning, integration, scale and institutional factors. He maintains that information technology creates value by supporting differentiation strategies.

Testing Porter's concepts in the networked economy led Rayport and Sviokla (1995) to advocate the existence of a virtual value chain that includes a sequence of gathering, organising, selecting, synthesising and distributing information. This revised concept corresponds better to the realities of virtual markets and in particular highlights the value of information (Shapiro \& Varian, 1999). These authors propose that e-business value creation can result from combinations of information, physical products and services, innovative configurations of transactions, and the reconfiguration and integration of resources, capabilities, roles and relationships among suppliers, partners and customers.

Theoretical frameworks continue to make valuable suggestions about possible sources of value creation (Hackney \& Burn, 2002; Hax \& Wilde, 2001; Scott, 1998; Zott, Amit \& Donlevy, 2000). Some insights are the results of research in the fields of entrepreneurship and strategic management. Value drivers raise the question of precisely which sources of value are of importance to e-businesses and whether such entities can be identified in the context of their businesses. Each theoretical framework, though, has some limitations when considered in the context of highly interconnected electronic markets (Amit \& Zott, 2001:500) and these authors maintain that this reinforces the need for the identification and prioritisation of the sources of value creation in e-business.

For some networked economy firms seeking to pinpoint the source of value, the temptation to attribute shareholder wealth creation solely to a business model was inevitable. The consequences have often been negative (Krantz, 2000). Given the correct context, the contribution of a business model has been proven to be nothing more than a useful starting point.

\section{The context of the business model}

Neither of the misconceptions among internet-spawned firms, that traditional process and content of business strategy is no longer relevant (Bertsch, et al., 2002) or that a good business model assures longevity (Krantz, 2000), is precisely valid. For most of the last century a well-crafted business strategy did deliver successful competitive advantage as many works on strategy will testify (Christensen \& Raynor, 2003; Porter, 1985; Thompson \& Strickland, 2001); some maintain that this will always be the case (Porter, 2001). However, as was shown earlier, the advent of the internet and its concomitant technologies introduced irreversible and fundamental changes to the domain of e-business. There is also the fallacy that business models alone indicate successful performance for such firms (De, Biju \& Abrham, 2001; Finkelstein, 2001; Kanter, 2001).

A model is an abstract representation of reality that defines a set of entities and their relationships. A business model most commonly describes the linkage between a firm's resources and functions and its environment. It is a contingency model that finds an optimal mode of operation for a specific situation in a specific market. The evolving business model concept is derived from a quest for value creation driven by environmental developments and infrastructural opportunities.

The business model, as a concept, is loosely defined in the literature. 'There has been no attempt to provide a consistent definition for a business model in the Internet context' (Mahadevan, 2000:56). According to Eisenmann (2002) business models are widely used but rarely defined. Practitioners once resorted to using the term to describe a unique aspect of a particular internet business venture but this resulted in confusion. Timmers (2000:32) concurs and states that 'the literature ... is not consistent in the usage of the term 'business model' and, moreover, often authors do not even provide a definition of the term'. The most quoted descriptions of business models are those of Timmers (2000), Amit and Zott (2001), Afuah and Tucci (2001) and Magretta (2002).

A business model is an architecture for product, service and information flows, including a description of the various business actors and their roles; a description of the sources of revenues, and a description of the potential benefits for the various business actors (Timmers, 2000). Amit and Zott (2001) view a business model as something that depicts the content, structure, and governance of transactions designed so as to create value through the exploitation of business opportunities. A business model includes the design of the transaction content, structure and governance. Afuah and Tucci (2001) find a business model to be a method by which the firm builds and uses its resources. Their business model consists of components, linkages between such components and the dynamics between them. In a larger context, Magretta (2002) sees the business model as a variation of the generic value chain underlying all businesses and comprising the business activities associated with making something and the business activities associated with selling something.

There are several other definitions which contribute to the overall concept and understanding of the context of the business model (The e-Factors report of the European 
Commission, 2002). Weill and Vitale (2001) view business models as a description of the roles and relationships among a firm's consumers, customers, allies, and suppliers that identifies the major flows of product, information, and money, and the major benefits to participants. Elliot (2002) posits that a business model specifies the relationships between different participants in a commercial venture, the benefits and costs to each and the flows of revenue. In an effort to develop a more comprehensive concept, Mahadevan (2000) combines business models into a blend of three business-critical streams: The value stream which identifies the value proposition for the business partners and the buyers, the revenue stream, a plan for assuring revenue generation for the business; and the logistical stream which addresses the supply chain of the business.

In their hierarchical representation of a business model, Petrovic, Kittl and Teksten (2001) build on the work of Alt and Zimmermann (2001) who identified generic elements present in most definitions. Petrovic et al. (2001) expand the business model contextual scope to include the internet and dynamic business evolution. Their analysis begins by viewing a company as an organised social system composed of interdependent parts delineated by identifiable boundaries whose boundary-spanning activities enable it to persist and evolve over time. They then posit that a business model describes the logic of a 'business system' which is the source of value creation. In similar fashion Applegate (2001) sees the business model as describing the structure, relationships among elements and its response to the real world.

From the numerous and often disparate definitions illustrated above, it can be seen that the business model as a concept is presently in the early stages of its evolution and benefits little from its turbulent and dynamic contextual environment. It is unwise at this juncture to attempt absolute claims of definitive explanation or even to opt for one single definition; in the context of this paper such an approach is also unnecessary.

The deep conceptual differences between strategy and business models could easily be confused by an ill-informed web entrepreneur. Given the naivety of some of the early web pioneers and their management inexperience it is not unlikely that this confusion contributed to some dot.com failures (Afuah \& Tucci, 2003; Chaffey, 2002). A business model explains how an enterprise works. It approximates a value chain as it includes a description of all the key business processes, the flows of products, services and information associated with these processes. It also describes the participants in the business venture, including the roles and relationships, as well as transactions completed between the players. It is interesting to note that neither competitive advantage or industry environment, nor the role of business models in securing these, are considered significant. Thompson and Strickland (2001:4-5) view a business model as being more focused than strategy and concerned with financial success. Strategy places more emphasis on competitive initiatives while business models deal with revenue flow and viability.

\section{Business models and strategy}

According to the classical view, strategy undergirds the relationship between an enterprise and its environment. In much of the foregoing analysis the preoccupation of strategy with futurity is clearly identified, as is the need for the firm to formulate effective strategies to defend its competitive position. Strategy formulation also relies on analytical procedures. The position-based view demonstrates the potential of rents flowing from appropriate industry positioning. The resource-based view, among others, shows the importance of effective systems and the ability, as a core competence of the firm, to rapidly deploy these to meet the dynamic needs of the business. The attitude of the firm toward identifying and managing risk is also a trait of an effective strategic management process. These then are some of the critical performance characteristics sourced from the study of strategy which are relevant to any business whether in the networked economy or not. Business models identify other factors.

In a perfunctory exploration of the strategy-business model relationship, two authorities on business models, Elliot and Magretta, have endeavoured to understand the linkage between the concepts. Elliot (2002:7) considers business strategies as specifying how a business model could be applied to the market to differentiate the firm from its competitors. Magretta (2002:3), in a broader sense, contends that '...a good business model remains essential to every successful organisation, whether it's a new venture or an established player'. Simplistically, both Elliot and Magretta agree that a business model is different from a business strategy in that the latter approach is more concerned with creating and defending an effective competitive position. Strategy, they contend, defines how a business organisation can do better than its rivals; it also embraces principles of differentiation. In another approach, Osterwalder and Pigneur (2002) believe that business models are the link missing between strategy and business processes. To them business models form the linkage between the planning and implementation levels of a business.

Different frameworks facilitate the identification of relevant characteristics which may predicate performance. They also provide useful ways to classify, organise or describe business models according to a set of principal dimensions.

There are three taxonomies of business models frequently encountered in the literature, each making its own unique contribution. In his framework Tapscott et al. (2000) classify collaborative businesses while Timmers (2000) uses degrees of innovation and functional integration. Rappa (2002) differentiates by source of revenue or revenue streams. The first two taxonomies are contextual while the latter is functional. Each of these frameworks identifies performance factors which can be attributed to business models and entails a different approach. Timmers (2000) examines business models from the point of innovation and functional integration. Tapscott et al. (2000) evaluate different business models from the point of collaborative business webs such as portals, intermediaries, and infomediaries. Rappa (2002) presents a view, where the one eminent factor of separation is the source of revenue. 
Expansions outside the firm boundaries are emerging. There is a trend towards a contingency approach where alliances and networks of companies are established as and when needed. There are competing trends towards tighter cooperation between competing value chains.

Business models have been further reduced, in the literature, to their individual components. The components of a business model reveal how firms structure and implement their models in the networked economy. A business model shows how a web firm plans to make money in the long term. The various components must work together and have clearly defined linkages. As with the definition of a business model, there is a dearth in the literature of agreement on the key components of a business model. The analysis of Afuah and Tucci (2001) is useful in that it relates the component to the strategy employed by the business.

In essence, therefore, business models shape the specific value-creation behaviour of a commercial web-enabled enterprise. Their product is the revenue-generating ability of the firm. Just as strategy is concerned with futurity, so business models have an undisguised passion for customercentricity as the source of value creation. Characterised by innovation, functional integration and alliances, economic innovativeness and the ability to leverage value from its value chain, the distinguishing characteristics of business models appear different from those of strategy, but are equally important contributors to effective web-enabled performance.

Business models, per se, are not complete. As the above analysis demonstrates, certain explicit considerations are absent from the business model concept. Not readily identifiable are the factors of strategic intent, sustainable competitive advantage, objective setting, environmental analysis and industry positioning, all of which are favoured by informed strategy.

In order to discourage accusations of parsimony the study on which this paper is based continues with a further analysis of electronic business ventures, beyond the realms of strategy and business models, in an effort to uncover what other factors could contribute to the performance of webenabled ventures. In the process, the concept of strategic architecture is given new meaning.

\section{Strategy and business models: underlap and strategic architecture}

So far the discussion has centred around the dangers of either blindly applying traditional strategy or relying solely on a business model for effective performance in the networked economy. The question arises whether there are any ingredients missing and what they might be.

It is effectively beyond the scope of this paper to comprehensively address this issue. In seeking answers a study is in progress that will identify the critical success factors sourced from strategy and business models, probe for missing elements and describe the linkages between them. It is possible, for example, given the emphasis on managing businesses in a turbulent, networked environment that being able to create and respond swiftly to market change and to match resources to dynamic and networked markets may require a firm to develop an ability for dynamic pliancy. In similar fashion, given the enthusiasm and dedication of the founders and e-entrepreneurs, and the need to unite and create a motivating climate for the people in the organisation, the existence of harmony, considered as the output of successful alignment behaviour, may also be indispensable. Finally, since many products developed for and traded on the internet are high in knowledge content, often with little or no material substance, managing knowledge may also be a key differentiator.

A theoretical research construct, the strategic architecture of commercial web-enabled enterprises (STRACWEN) has been developed. Its dimensions are based on strategy and business models, mediated by configuration theory (Miller, 1986), dynamic capability (Eisenhardt \& Martin, 2000) and knowledge management (Skyrme, 2000 \& 2001). This construct will be used to measure the strategy of ecommerce businesses and correlate it with their performance. The phrase 'Strategic Architecture' has been used before but in a different context (refer Hamel \& Prahalad, 1990; Kiernan, 1993).

\section{Conclusion and implications}

The new rules for business success in the networked economy place a premium on value creation and its concomitant proposition. To benefit most from the Schumpeterian rents spawned by the internet and its technologies, firms have employed value creation concepts which have been historically grounded on internalising transactions and improving efficiencies, both of which lend themselves to the application of technology. In so doing however the new entrepreneurs have tended to underplay the value of business strategy, often with inauspicious consequences.

The prima facie role of strategy is the pursuit of competitive advantage. Its rich heritage spanning almost a century of business endeavour has produced a valuable compendium of proven tools and techniques. The purpose of strategy is the achievement of a desired future. In this process competitive behaviour, objective setting, environmental analysis, analytical procedures, risk management and effective systems have become some of its valuable characteristics.

In contrast, the business model is a more recent phenomenon, augmented by the internet and underpinning the value creation process. When intuitively and irresponsibly applied to web-spawned business, it has created a mistaken belief amongst less-informed businessmen that it is the sole means to sustainable commercial viability.

Internet business is evolving and firms are grappling with the new rules for competing successfully in the networked economy. Developing and implementing new or changed business models requires entrepreneurial flair and careful management of risk. The leaders of such ventures develop business models aimed at releasing latent value in 
technology but in the process become blinded to the fact that although the economic rules may be different, the basic ethos of business remains the same. This view may also have contributed towards the disregard for the value of strategy.

The dot.com failures of 2000 have given no credence to the demonstration of management possessing a clear grasp of the relationship between strategy and business models. Neither has the loose definition of a business model helped clarify the issue. A business model is the product of management's inexorable quest for the best customer value proposition, wholly concerned with customer centricity. Not readily discernable from the pure business model however, are the factors of strategic intent, sustainable competitive advantage, objective setting, environmental analysis and industry positioning, all of which are elements of strategy.

Neither strategy nor business models, in isolation, indicate success for electronic businesses; both are required, and more, as this paper has argued. Active debate between strategists and e-business practitioners will eventually lead to the realisation that strategic intent and value creation remain the foundations for effective performance of every networked economy firm. From that moment, and only from that moment, will the sleeping partners of strategy and business models cease being strange.

\section{References}

Afuah, A. \& Tucci, C. L. 2001. Internet business models and strategies: Text and cases. $1^{\text {st }}$ International edition. New York: McGraw-Hill/Irwin.

Afuah, A. \& Tucci, C. L. 2003. Internet business models and strategies: Text and cases. $2^{\text {nd }}$ Edition. New York: McGraw-Hill/Irwin.

Alt, R. \& Zimmerman, H.-D. 2001. 'Guest editors note'. In Schmit, B.F., Alt, R., Zimmerman, H-D. \& Buchet, B. EMElectronic Markets Journal, 11:1-15.

Amit, R. \& Zott, C. 2001. 'Value creation in e-business', Strategic Management Journal, 22:493-520.

Anderson, C. \& Zeithaml, C. 1984. 'Stage of the product life cycle, business strategy and business performance', Academy of Management Journal, 27:5-24.

Ansoff, H. I. 1968. Corporate strategy: An analytic approach to business policy for growth and expansion. $1^{\text {st }}$ Edition. Harmondsworth: Penguin Books.

Applegate, L. M. 2001. E-business models: Making sense of the Internet business landscape. Upper Saddle River, N.J: Prentice Hall.

Awad, E. 2002. Electronic commerce. Upper Saddle River: Prentice Hall.

Bakos, J. Y. 1997. 'Reducing buyer search costs: Implications for electronic marketplaces', Management Science, 43(12):1676-1692.
Barney, J. 1991. 'Firm resources and sustained competitive advantage', Journal of Management, 17:99-120.

Becker, M. C. \& Knudsen, T. 2002. 'Schumpeter 1911. Farsighted visions on economic development', American Journal of Economics and Sociology, 61(2):387-403.

Bertsch, T., Busbin, J., \& Wright, N. 2002. 'Gaining competitive advantage in e-tailing through marketing management and value-added uses of technology', Competitiveness Review, 12(2):49-56.

Brown, S. L. \& Eisenhardt, K. M. 1997. 'The art of continuous change: Linking complexity theory and timepaced evolution in relentlessly shifting environments', Administrative Science Quarterly, 42:1-34.

Chaffey, D. 2002. E-Business and E-Commerce management: Strategy, implementation and practice. $1^{\text {st }}$ Edition. Harlow: Pearson Education.

Chandler, A. D. 1962. Strategy and structure: Chapters in the history of the industrial enterprise. Cambridge: MIT Press.

Chandler, A. D. 1969. Strategy and structure : Chapters in the history of the American industrial enterprise. Paperback edition. Cambridge: MIT Press.

Christensen, C. M. \& Raynor, M. E. 2003. 'Why hard-nosed executives should care about management theory', Harvard Business Review, September:66-74.

Cohen, A. 2002. The perfect store: Inside eBay. Boston: Little Brown and Company.

D'Aveni, R. A. 1994. Hypercompetition: Managing the dynamics of strategic maneuvering. New York: Free Press.

D'Aveni, R. A. 1998. 'Waking up to the new era of hypercompetition', The Washington Quarterly, Winter:183195.

De, R., Biju, M., \& Abraham, D. M. 2001. 'Critical constructs for analyzing e-businesses: investment, user experience and revenue models', Logistics Information Management, 14(1/2):137-148.

Downes, L. \& Hui, C. 1998. Unleashing the killer app: Digital strategies for market dominance. Boston: Harvard Business School.

Drucker, P. F. 1946. Big business. London: Heinemann.

Economist, The. 2000. A survey of the new economy. 23 September.

Eisenhardt, K. M. \& Martin, J. A. 2000. 'Dynamic capabilities: What are they', Strategic Management Journal, 21:1105-1121.

Eisenmann, T. R. 2002. Internet business models: Text and cases. International edition. New York: McGraw-Hill. 
Elliot, S. 2002. Electronic commerce: B 2 C strategies and models. Chichester, U.K: John Wiley.

European Commission. 2002. 'E-Factors report, part 1: Overview and current trends on e-business models'. Information Society Technologies, Brussels:1-186

Evans, P. \& Wurster, T. 1999. Blown to bits: How the new economics of information transforms strategy. Boston: Harvard Business School Press.

Fahey, L. \& Christensen, H. K. 1986. 'Evaluating the research on strategy content', Journal of Management, 12 (2): 167-183.

Fahy, J. \& Hooley, G. 2002. 'Sustainable competitive advantage in electronic business: towards a contingency perspective on the resourced-based view', Journal of Strategic Marketing, 10:241-253.

Finkelstein, S. 2001. 'The myth of managerial superiority in Internet startups: An autopsy', Organizational Dynamics, 30(2):172-185.

Galbraith, C. \& Schendel, D. 1983. 'An empirical analysis of strategy types', Strategic Management Journal, 4:153173.

Hackney, R. \& Burn, J. 2002. 'Strategies for e-markets: toward a unified management model'. Paper presented at the Eighth Americas Conference on Information Systems, Dallas, Texas: 678-687.

Hambrick, D. C. \& Schecter, S. 1983. 'Turnaround strategies for mature industrial-product business units', Academy of Management Journal, 26:231-248.

Hamel, G. \& Prahalad, C. K. 1990. 'The core competence of the corporation', Harvard Business Review, May-June:7991.

Hamel, G. \& Prahalad, C. K. 1994. 'Competing for the future', Harvard Business Review, 72(4):122-128.

Hamel, G. \& Prahalad, C. K. 1996. 'Competing in the new economy: Managing out of bounds', Strategic Management Journal, 17(3):237-242.

Hax, A. \& Wilde, D. 2001. 'The Delta model - Discovering new sources of profitability in a networked economy', European Management Journal, 19(4):379-391.

Henderson, B. D. 1989. 'The origin of strategy', Harvard Business Review, November - December: 139-143.

Honda, G. \& Martin, K. 2002. The essential guide to internet business technology. Upper Saddle River: Prentice Hall.

J P Morgan. 1999. E-tailing and the five Cs. New York.
Johnson, G., Melin, L., \& Whittington, R. 2003. 'Micro strategy and strategizing: Towards an activity-based view', Journal of Management Studies, 40(1):3-22.

Kalakota, R. \& Robinson, M. 2001. e-Business 2.0 Roadmap for success. New York: Addison-Wesley.

Kanter, R. M. 2001. 'The ten deadly mistakes of WannaDots', Harvard Business Review, January: 91-100.

Kay, J. 1993. 'The structure of strategy', Business Strategy Review, 4:17-37.

Kiernan, M. J. 1993. 'The new strategic architecture: learning to compete in the twenty-first century', Academy of Management Executive, 7 (1)

Kim, E., Nam, D.-I., \& Stimpert, J. L. 2001. 'Testing the applicability of Porter's generic strategies in the digital age: a study of Korean cyber malls'. Paper presented at the 21 st Annual International Strategic Management Conference, San Francisco.

Koch, R. 2000. The Financial Times Guide to strategy: How to create and deliver a useful strategy. ( $2^{\text {nd }}$ Edition). Harlow, UK: Pearson Education Limited.

Krantz, M., 2000. 'Dot-coms without plans die.' [Online] Available: www.usatoday.com/money/dotcoms/dot038.htm. Accessed: 2 April 2003.

Levitt, T. 1960. 'Marketing myopia', Harvard Business Review, July - August: 45-56.

Magretta, J. 2002. 'Why business models matter', Harvard Business Review, May: 3-8.

Mahadevan, B. 2000. 'Business models for internet-based ecommerce: an anatomy', California Management Review, 42(4): 55-69.

Miller, D. 1986. 'Configurations of strategy and structure: Towards a synthesis', Strategic Management Journal, 7: 233-249.

Murray, A. I. 1988. 'A contingency view of Porter's 'Generic Strategies', Academy of Management Review, 13(3):390-400.

Osterwalder, A. \& Pigneur, Y. 2002. 'An e-business model ontology for modelling e-business'. Paper presented at the 15 th Bled Conference on E-Commerce, Bled, Slovenia.

Petrovic, O., Kittl, C. \& Teksten, R. D. 2001. 'Developing business models for ebusiness'. Paper presented at the International Conference on Electronic Commerce 2001, Vienna.

Porter, M. E. 1980. Competitive strategy. Techniques for analysing industries and competitors. New York: The Free Press. 
Porter, M. E. 1985. Competitive advantage: Creating and sustaining superior performance. New York: Free Press.

Porter, M. E. 2001. 'Strategy and the Internet', Harvard Business Review, March: 63 - 78.

Priem, R. \& Butler, J. E. 2001. 'Is the resource-based 'view' a useful perspective for strategic management research?' Academy of Management Review, 26(1): 22-40.

Rappa, M. 2002. 'Business models on the web: Managing the digital enterprise'. [Online] digitalenterprise.org/models/models.html. Accessed: 7 November 2002.

Rayport, J. \& Sviokla, J. 1995. 'Exploiting the virtual value chain', Harvard Business Review, 73(6): 75-85.

Rayport, J. F. \& Jaworski, B. J. 2001. e-Commerce. New York: McGraw-Hill.

Robinson, R. \& Pearce, J. 1988. 'Planned patterns of strategic behavior and their relationship to business-unit performance', Strategic Management Journal, 9: 43-60.

Sampler, J. 1998. 'Redefining industry structure for the information ag', Strategic Management Journal, 19(4): $343-355$.

Schendel, D. \& Hofer, C. W. 1979. Strategic management: A new view of business policy and planning. Boston: Little Brown.

Schumpeter, J. 1934. The theory of economic development: An inquiry into profits, capital, credit, interest, and the business cycle. Cambridge: Harvard University Press.

Scott, M. C. 1998. Value drivers: The manager's framework for identifying the drivers of corporate value creation. Chichester: John Wiley \& Sons.

Shapiro, C. \& Varian, H. 1999. Information rules: A strategic guide to the network economy. Boston: Harvard Business School Press.

Skyrme, D. J. 2000. Knowledge networking. Creating the collaborative enterprise. Oxford: Butterworth-Heinemann.

Skyrme, D. J. 2001. Capitalising on knowledge. From ebusiness to k-business. Oxford: Butterworth-Heinemann.

Sloan, A. P. 1963. My years with General Motors. London: Sedgewick \& Jackson.

Tapscott, D., Ticoll, D. \& Lowy, A. 2000. Digital capital. Harnessing the power of business webs. 1st Edition. Boston: Harvard Business School Press.

Tapscott, D. 2001. 'Rethinking strategy in a networked world (or Why Michael Porter is wrong about the Internet)', Strategy + Business, 3rd Quarter:1-8.
Thompson, A. A. \& Strickland, A. J. 2001. Strategic management concept and cases. 12th Edition. New York: McGraw-Hill Higher Education.

Timmers, P. 2000. Electronic commerce: Strategies and models for business to business trading. March 2000 edition. Chichester, England: John Wiley and Sons Ltd.

Weill, P. \& Vitale, M. R. 2001. Place to space: Migrating to ebusiness models. Boston, Mass: Harvard Business School Press.

Welborn, R. \& Kasten, V. 2003. The Jericho principle. How companies use strategic collaboration to find new sources of value. New Jersey: John Wiley \& Sons.

Williamson, O. E. 1983. Organizational innovation: The transaction cost approach. Lexington: Lexington Books.

Zack, M. H. 1999. Knowledge and strategy. Woburn: Butterworth-Heinemann.

Zott, C., Amit, R. \& Donlevy, J. 2000. 'Strategies for value creation in e-commerce: Best practice in Europe', European Management Journal, 18(5): 463-475. 